\title{
INTRODUCTION TO THE SYMPOSIUM ON GOVERNING HIGH SEAS BIODIVERSITY
}

\author{
Cymie R. Payne*
}

Ocean areas beyond national jurisdiction are a global commons with many intersecting regional and sectoral interests, presenting complex governance challenges akin to those implicated by outer space, Antarctica, and cyberspace. The international community's legal interest in such commons resources differs from traditionally defined sovereign legal interests, leading to a need for innovation. ${ }^{1}$ Among other things, thoughtful consideration of institutional form is required to facilitate cooperation, coordination, and capacity on a global scale.

This symposium explores this challenge of institutional design through the lens of an emerging international treaty to govern marine biological diversity in areas beyond national jurisdiction (a topic referred to as "BBNJ"). In December 2017, the UN General Assembly decided to convene an intergovernmental conference "to elaborate the text of an internationally legally binding instrument under the United Nations Convention on the Law of the Sea on the conservation and sustainable use of marine biological diversity of areas beyond national jurisdiction." ${ }^{2}$ Negotiations on such an internationally legally binding instrument (ILBI) will begin in September 2018.

States and ocean advocates have identified this moment as a crucial juncture in terms of risks and opportunities for governing the living marine environment. A formal legal view of ocean governance shows a constitutional framework - the UN Convention on the Law of the Sea (UNCLOS)—ordering a web of treaties, institutions, and implementing agreements. (The ILBI will be the third implementing agreement to UNCLOS. ${ }^{3}$ ) The view looks different from the perspective of those who actually spend time in salt water, such as fishers, submarine cable companies, miners, and shipping companies. For them, ocean governance appears fragmented and more focused on specialized, narrower interests. Many new entities are engaging in ocean activities, while at the same time sovereigns are challenging UNCLOS's constitutional order-for example, China's rebuff of the South China Sea arbitral award issued by a tribunal established under UNCLOS, to which China is a party. ${ }^{4}$

The six essays in this symposium address a key challenge for the negotiation of the ILBI: will it be an interstitial instrument or a new consolidated regime? Though this question has immediate practical importance, it also relates to ongoing conversations regarding regime interactions, global constitutionalism, fragmentation, multilateralism, global administrative law, transnational governance, and treaty design.

* Associate Professor, Rutgers University; Chair, IUCN World Commission on Environmental Law, Ocean, Coasts, and Coral Reefs Specialist Group.

${ }^{1}$ Cymie Payne, Collective Responsibility for Sound Resource Management: Erga Omnes Obligations and Deep Seabed Mining, in ENVIRONMENTAL Rule of Law: Trends from the Americas (2015).

${ }^{2}$ G.A. Res. 72/249 (Dec. 24, 2017). For a discussion of the Preparatory Committee and earlier processes leading to the resolution, see Cymie Payne, Biodiversity in High Seas Areas: An Integrated Legal Approach, 21:9 ASIL InsigHTs (2017).

${ }^{3}$ See also Agreement Relating to the Implementation of Part XI of the Law of the Sea Convention, Nov. 16, 1994, 1836 UNTS 3 (entered into force July 28, 1996); Agreement for the Implementation of the Provisions of the United Nations Convention on the Law of the Sea of 10 December 1982 relating to the Conservation and Management of Straddling Fish Stocks and Highly Migratory Fish Stocks, Aug. 4, 1995, 2167 UNTS 3 (entered into force Dec. 11, 2001).

${ }^{4}$ Lucy Reed \& Kenneth Wong, Marine Entitlements in the South China Sea: The Arbitration Between the Philippines and China, 110 AJIL 746 (2016).

The American Society of International Law and Cymie R. Payne (C) 2018. This is an Open Access article, distributed under the terms 


\section{The Legacy of David Caron}

David Caron was coeditor for this symposium until his untimely passing in February 2018. He had a keen appreciation of the real world context in which international law functions, and an eye for its theoretical architecture. One of Caron's enduring interests was governance of the Arctic, a region he first experienced as a U.S. Coast Guard navigator and diver. ${ }^{5}$ In his 2011 Library of Congress speech, he offered three images of the Arctic and their implications for governance that suggest interesting analogies to the problems of high seas governance with which these authors engage.

His first Arctic image was of a place that, until the early 1990s, was sufficiently remote and unpopulated that "law and politics are dormant, asleep," and if there were potential conflicts, "there is no urgency to resolving them." ${ }^{\circ} \mathrm{He}$ next inverted this first image, showing that the Arctic is actually inhabited by people who have lived there with their own laws and politics since before European contact. Most of us similarly picture the high seas as a blank surface that has been little troubled by disputes, yet its long-time "inhabitants"-fishers, sailors on cargo ships, submarine crews, and more recently telecommunications cable-layers - each have their own sectoral legal regimes and politics in a region that constitutes 46 percent of the Earth's surface.

In his second Arctic image of melting ice, Caron invoked climate change and its potential to open access to Arctic natural resources within circumpolar states' 200-nautical mile exclusive economic zones and their extended continental shelves. This, he told us, would lead states to claim newly accessible natural resources in areas where international law allocates and mediates national entitlements. Similarly, as technology and commerce open access to ocean natural resources in marine areas beyond national jurisdiction, the resulting claims to the extended continental shelf and disputes over maritime boundaries focus attention on regional conflicts and draw in national security concerns to already complex natural resource contests.

In Caron's future-oriented third Arctic image, summer ice will have melted, new access will encourage an enlarged group of states to assert rights, and human activities in the Arctic will increase. ${ }^{7}$ His implicit point is that these changes will test the ocean zoning scheme that was codified by UNCLOS 8 just over thirty years ago. It is even more clear today than in 2011 that climate change will also affect living resources of the high seas, for example by causing fish to migrate to cooler waters. ${ }^{9}$ Novel, adaptive governance tools are needed for a planet that is dynamically, rapidly changing.

Caron's conclusion resonates with this symposium, which we dedicate to his legacy:

The first image gives us a respect for nature ..., it reminds us to be cautious, and it carries in it a sense of loss that is appropriate. The second image in contrast carries within it a sense of opportunity and of excitement that is appropriate; it gives us frontiers and challenges. Finally, the third image reminds us that the excitement that goes with frontiers and challenges can come at a great price, it reminds that change brings both development and destruction and it instructs that the first and foremost challenge is that we govern our affairs responsibly. ${ }^{10}$

\footnotetext{
${ }^{5}$ David Caron served in the U.S. Coast Guard; as codirector of the Law of the Sea Institute; as the Maxeiner Distinguished Professor of Law at the University of California, Berkeley; as Dean of the Dickson Poon School of Law, King's College, London; as President of the American Society of International Law; as member of the AJIL Board of Editors; twice as Judge ad hoc of the International Court of Justice; and as Member of the Iran-U.S. Claims Tribunal— to highlight just a few facets of his distinguished career.

${ }^{6}$ David D. Caron, Images of the Arctic and the Futures They Suggest (Law Library of Congress Lecture, Mar. 30, 2011).

${ }^{7}$ Id. at 15.

${ }^{8}$ UN Convention on the Law of the Sea, Dec. 10, 1982, 1833 UNTS 397 [hereinafter UNCLOS].

9 See James W. Morley et al., Projecting Shifts in Thermal Habitat for 686 Species on the North American Continental Shelf, 13:5 PLOS ONE (2018).

${ }^{10}$ Caron, supra note 6, at 21-22.
} 


\section{Governing Biodiversity Beyond National Jurisdictions}

When the BBNJ negotiation begins in September 2018, it will be an important step toward governance of areas beyond national jurisdiction more broadly, and it will either strengthen or weaken basic principles of how humanity shares the Earth. The General Assembly resolution identified four topics to be addressed: "in particular, together and as a whole, marine genetic resources, including questions on the sharing of benefits, measures such as areabased management tools, including marine protected areas, environmental impact assessments and capacitybuilding and the transfer of marine technology." 11 There is funding for four meetings over two years, but the negotiation is likely to take considerably longer.

The ILBI must balance three competing legal principles enshrined in UNCLOS. One is freedom of the high seas, a principle identified with economic and security interests and representing an open access view of the ocean, where any state may navigate, fly over, lay submarine cables and pipelines, construct installations, conduct scientific research, fish, or mine as it chooses, and keep any benefits accrued for itself, as long as it does so with due regard for other states' rights in the high seas. ${ }^{12}$ The second principle is the common heritage of humankind, reflecting the more modern perspective of an Earth with limited resources to be shared fairly among humans, ${ }^{13}$ and advocated most strongly by the developing states. The third principle is states' obligation to protect the marine environment; ${ }^{14}$ its strongest advocate might be said to be scientific facts. The negotiation, tasked with "the conservation and sustainable use" of BBNJ, ${ }^{15}$ represents an explicit commitment to all three principles: intensified use of the high seas, protection of its ecological integrity, and consideration of social needs.

\section{The Challenge of Legal Complexity}

While deftly balancing background principles, negotiators are asked to accomplish a tricky practical task. The high seas are governed by UNCLOS, bilateral and multilateral agreements, customary international law, the domestic law of flag states for ships that ply the ocean, and soft law principles. The negotiating mandate states that "this process and its result should not undermine existing relevant legal instruments and frameworks and relevant global, regional and sectoral bodies." 16 Simultaneously, negotiators must be mindful of the UNCLOS preamble's admonition "that the problems of ocean space are closely interrelated and need to be considered as a whole."

Margaret Young and Andrew Friedman address the particular challenge of a legal landscape littered with agreements as well as significant gaps. ${ }^{17}$ The authors identify a taxonomy of light, medium, and heavy institutional designs that states might adopt to oversee the four components of the BBNJ negotiation mandate and enhance coordination

11 G.A. Res. $72 / 249$ para. 2 (Dec. 24, 2017).

12 UNCLOS, supra note 8 , art. 87.

13 The common heritage is closely, but not exclusively, associated with deep seabed minerals. Article 136 of UNCLOS states that the seabed, ocean floor and subsoil in areas beyond national jurisdiction and "its resources are the common heritage of mankind." The concept of common heritage was introduced by Arvid Pardo in reference to the water column as well, and Article 4 of the Agreement Governing the Activities of States on the Moon and Other Celestial Bodies (the "Moon Treaty") similarly refers to the exploration and use of the moon as "the province of all mankind."

${ }^{14}$ UNCLOS, supra note 8, art. 192.

${ }^{15}$ G.A. Res. 72/249 (Dec. 24, 2017); Biodiversity Beyond National Jurisdiction: Regimes and Their Interaction.

${ }^{16}$ G.A. Res. 69/292 para. 3 (June 19, 2015).

${ }^{17}$ Margaret Young \& Andrew Friedman, Biodiversity Beyond National Jurisdiction: Regimes and Their Interaction, 112 AJIL UNBOUND 123 (2018). 
with other relevant bodies. They underscore the risks of "entrenching positions instead of opening them to contestation and evolution" and emphasize the need for an "adaptive approach to existing and future institutions."

David Freestone examines the important and longstanding problem of coordinating and obtaining universal compliance with regulations in the high seas, and in particular for marine protected areas (MPAs). ${ }^{18}$ MPAs are an important tool to conserve biological diversity, providing breeding, sheltering, and feeding zones for life forms that may be hunted or otherwise disturbed by human activities in other parts of the ocean. Yet the freedoms of the high seas inhibit all but consent-based measures to restrict most of those activities within MPAs in areas beyond national jurisdiction. Freestone probes whether a minimalist approach of relying on existing sectoral arrangements could provide sufficient stewardship to protect an area designated as an MPA. He argues that the mixed experience of the Sargasso Sea initiative reveals the need for a centralized or coordinating body with a wider mandate and a deeper commitment to environmental principles than regimes limited by sector or geography can provide. On the other hand, he does not necessarily see the need for a new organization with authority over all other bodies. Rather, he envisions a science-driven intergovernmental process, conducted in consultation with the relevant regional or sectoral bodies but with the power to impose its own solutions, or even restrictions, if necessary. ${ }^{19}$

Timo Koivurova and Richard Caddell draw lessons from the regulatory challenges facing the Arctic in light of climate change and "a slow but discernible anthropogenic creep." 20 These authors see the ILBI as superior to new regional agreements for improving high seas governance in the Arctic. They argue the ILBI can and should leverage existing institutions like the Arctic Council by establishing broad methodological consensus regarding such regulatory tools as environmental impact assessments and the designation of high seas MPAs. In turn, a creatively designed ILBI offers the possibility of supporting rather than supplanting regional arrangements, such as the innovative Arctic Council.

Turning from regional governance to sectoral regulation, Tara Davenport explains that the right to lay submarine cables is explicitly designated a freedom of the seas under UNCLOS. ${ }^{21}$ Laying and maintaining submarine cables is surely one of the least-known human activities in the world ocean, yet we depend on it for 95 percent of international telecommunications, including the Internet. Cables are thin but long, and while they generally lie on the seabed, their installation, maintenance, and removal can impact fragile marine ecologies. Moreover, the current negotiation should account for possible submarine power cables and oil and gas pipelines in these areas. Davenport argues against creating a blanket exemption from new regulation for the cable industry, proposing instead a balanced regime that imposes nuanced regulation attuned to the industry's generally minimal environmental impact and its need for confidentiality and access. By building that flexibility into the ILBI, this approach would also address the differing needs of new or emerging uses of the world ocean by providing a light regulatory touch that can become more assertive if facts in the water warrant it.

Stephen Minas points to the broad agreement amongst BBNJ Preparatory Committee participants that technology transfer should be country-driven, sustainable, and consistent with UNCLOS. ${ }^{22} \mathrm{He}$ reminds us that Article 266 of UNCLOS has long been a largely unfulfilled exhortation for technology transfer, with limited

18 David Freestone, The Limits of Sectoral and Regional Efforts to Designate High Seas Marine Protected Areas, 112 AJIL UnBOund 129 (2018).

19 See Dire Tladi, The Proposed Implementing Agreement: Options for Coherence and Consistency in the Establishment of Protected Areas beyond National Jurisdiction, 30 Int'L J. MARINE \& COASTAL L. 654 (2015).

${ }^{20}$ Timo Koivurova \& Richard Caddell, Managing Biodiversity Beyond National Jurisdiction in the Changing Arctic, 112 AJIL UNBOUND 134 (2018).

21 Tara Davenport, The High Seas Freedom to Lay Submarine Cables and Pipelines and the Protection of the Marine Environment: Challenges in High Seas Governance, 112 AJIL Unbound 139 (2018).

${ }^{22}$ Stephen Minas, Marine Technology Transfer Under a BBNJ Treaty: A Case for Transnational Network Cooperation, 112 AJIL UNBOUND 144 (2018). 
implementation by the International Maritime Organization. The author identifies networks for technology transfer developed by the UN Framework Convention on Climate Change and the Convention on Biological Diversity as effective and efficient models for the BBNJ treaty. These network approaches allow countries in need of technology to make requests to which public, private, and international possessors of the technology can respond, overcoming many of the barriers to technology delivery.

James Kraska, on the other hand, argues that costs to national security interests will check the ambitions for a strong, progressive BBNJ instrument. ${ }^{23}$ Though not on the BBNJ Preparatory Committee agenda, security is a central consideration in ocean governance. Kraska's essay chiefly focuses on states' rights and duties, concluding that only an interstitial approach will prove acceptable to powerful states. He raises three interlinked issues. One questions the meaning of UNCLOS's reservation of the ocean for peaceful purposes in light of increased military presence there. Another is the tension between the goal of restrictively regulated MPAs and pressure from military powers to protect their freedom of navigation throughout the high seas. The third is simple inertia from maritime powers unwilling to risk the imagined present stability of the UNCLOS-centered regime for uncertain innovations in a new legal instrument. Finally, Kraska suggests that possessory attitudes toward marine genetic resources—and perhaps other ocean riches-will lead technologically capable states to insist on high seas freedoms and to reject principles of common heritage or access and benefit-sharing, reflecting an archaic strategy of mercantilism. This too has a national security dimension to the extent that control of advances in biotechnology benefits national economies and possibly provides inputs for bio-weapon development. For Kraska, a dose of constructive ambiguity and use of general obligations rather than specific mandates may enable agreement even when some parties seem to hold nonnegotiable positions — such as the national security concerns of the maritime powers and, more generally, states' perception of their exclusive sovereign rights and jurisdiction.

States have shown significant commitment to the BBNJ process so far, making it worth a moment's reflection on what they hope to achieve. Certain benefits are inherent in the nature of any international agreement: being able to oppose the instrument's provisions against other parties to achieve a national goal (whether protecting whales, tuna fisheries, or naval navigation rights); improving coordination for management of complex shared environments; reducing transaction costs; and acquiring competence within international bodies created by the agreement. $^{24}$ These are, of course, set off against the cost of constrained behavior and the financial costs of maintaining treaty bodies.

The perspectives collected in this symposium identify challenges for the design of ambitious new legal regimes and hint at possible ways to finesse conflicts and defensiveness. In doing so, these essays touch on some of the sectors and strategies that states must consider to address the high seas governance gap, but they are not and cannot be comprehensive. They have omitted, for example, the important role of shipping, an intrusive and widespread activity in areas beyond national jurisdiction. The symposium does not cover the serious, known environmental impacts from long-range transport of land-based pollutants, including plastics, persistent organic pollutants, air pollutants, and heavy metals, which raises an entirely different set of legal issues. And it does not touch on radiation pollution from past and future disposal of nuclear materials and chemicals, both wastes and weapons, in areas beyond national jurisdiction. ${ }^{25}$ Nonetheless, we hope that these essays help to clarify some of the issues and to advance the basis for governing areas beyond national jurisdiction in light of imperfect regimes, competing interests, and differing perspectives on background principles.

${ }^{23}$ James Kraska, National Security Considerations for a Binding Instrument on Managing Biodiversity Beyond National Jurisdiction, 112 AJIL UnBOUND 150 (2018).

${ }^{24}$ David H. Anderson, Resolution and Agreement Relating to the Implementation of Part XI of the UN Convention on the Law of the Sea: A General Assessment, in 55 HeIdelBerg J. INT'L L. 275, 288-89 (1995).

25 The Oceans in the Nuclear Age: Legacies and Risks (David D. Caron \& Harry N. Scheiber eds., 2014). 